\title{
Ensuring the competitiveness of innovation projects through the management of their life cycle parameters
}

\author{
Elena Minaeva ${ }^{1}$, Olga Yutkina $^{1}$, Yuliya Anoshina ${ }^{1}$, Ekaterina Maslyukova ${ }^{1}$ and Irina \\ Karapetyan ${ }^{2, *}$ \\ ${ }^{1}$ Russian State University of Justice, 69, Novocheremushkinskaya street, Moscow, 117418, Russia \\ ${ }^{2}$ Moscow state University of technology and management. K. G. Razumovsky, Zemlyanoy Val street, \\ 73, Moscow, 109004, Russia
}

\begin{abstract}
The purpose of this paper is to develop guidelines for the assessment and implementation of innovation projects, which ensure its competitiveness through the management of life cycle parameters. The paper substantiates and generalizes the theoretical aspects of innovation project management, explores and systematizes the principles of developing a competitive innovation project. Based on the analyzed competitiveness factors, an integrated assessment indicator is proposed and an algorithm is formed that allows choosing the optimal set of risk management methods within the framework of an innovation project. In addition, modern methods for monitoring the competitiveness of innovation projects have been proposed, which allow determining the main areas of implementation and the level of research intensity of innovations.
\end{abstract}

\section{Introduction}

An innovative project is associated with the creation, development and dissemination of innovation. In market conditions, manufacturers of products or services are constantly forced to look for ways to reduce production costs and enter new markets, and organizations that have first mastered effective innovations receive a significant advantage over their competitors. An innovative project is a broader concept and can be considered from various perspectives and with varying degrees of detail [1].

Firstly, it represents the implementation of research, scientific, technical, innovative, industrial activity and marketing. Secondly, it can be understood as the stages of the life cycle of an innovation from the emergence of an idea to its development and dissemination. Thirdly, from a financial point of view, it can be considered as a process of financing and investing in the development and distribution of a new type of product or service.

\footnotetext{
* Corresponding author: svgvgy@mail.ru
} 
The key role in the formation of an innovative project at the present stage is played by its competitiveness. The competitiveness of an innovative project is a dynamic property that characterizes its ability to be implemented in a competitive market and reflects the attractiveness of the project for both consumers and investors, which is determined by the degree of its economic efficiency.

\section{Materials and methods}

An analysis of all of the above provisions made it possible to identify the main factors of a competitive innovation project, in accordance with which a number of principles for its development were proposed (Figure 1).

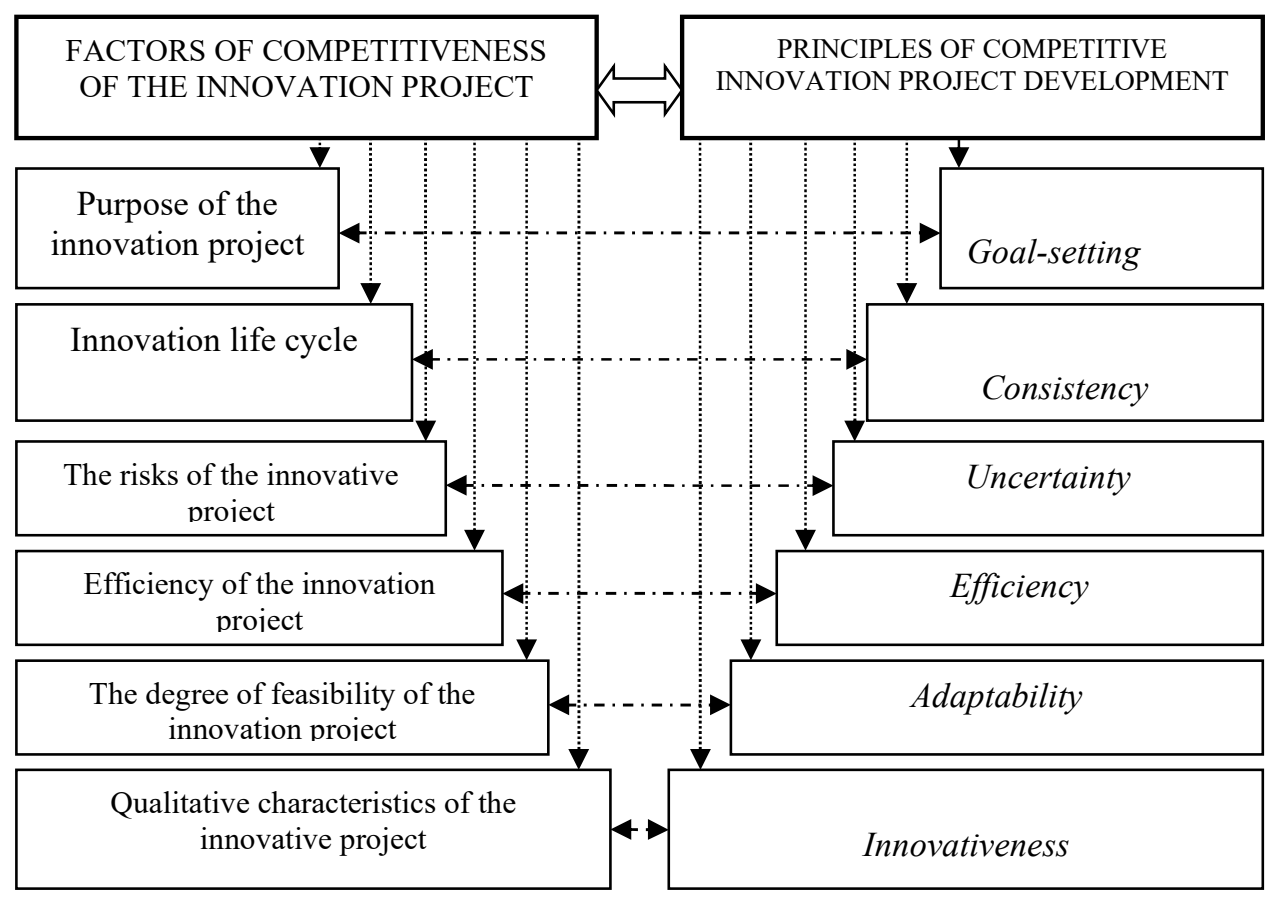

Fig. 1. Factors of competitiveness of the innovation project.

Based on the foregoing, the following can be attributed to the principles of developing a competitive innovation project [2].

1. The principle of goal-setting - involves a set of sub-goals, and decisions are assessed in terms of their optimal combination.

2. The principle of consistency, in which an innovative project is considered as a complex dynamic system that includes interconnected elements.

3. The principle of uncertainty, taking into account systematic and random factors that affect the process, and ignoring random factors reduces the reliability of the analysis.

4. The principle of efficiency, involving the choice of an innovative project with minimal costs to achieve a long-term planned result, which means increased efficiency with other things being equal.

5. The principle of adaptability, involving the implementation of a particular innovation in accordance with the capabilities of the economic and innovation environment. 
6. The principle of innovativeness, which assumes the novelty of the implemented innovation.

\section{Results}

Based on the principles of a competitive innovation project, a model is proposed that allows the development and implementation of economically sound and competitive innovation projects (Figure 2).

When implementing this model, a sequence of states of an innovation project is formed depending on the life cycle of the innovations included in it, which allows switching from the existing characteristic point of development to the desired one. The model allows creating the maximum possible competitiveness of an innovation project based on the combination of several innovations and reflects the sequence of states of innovation processes [3].

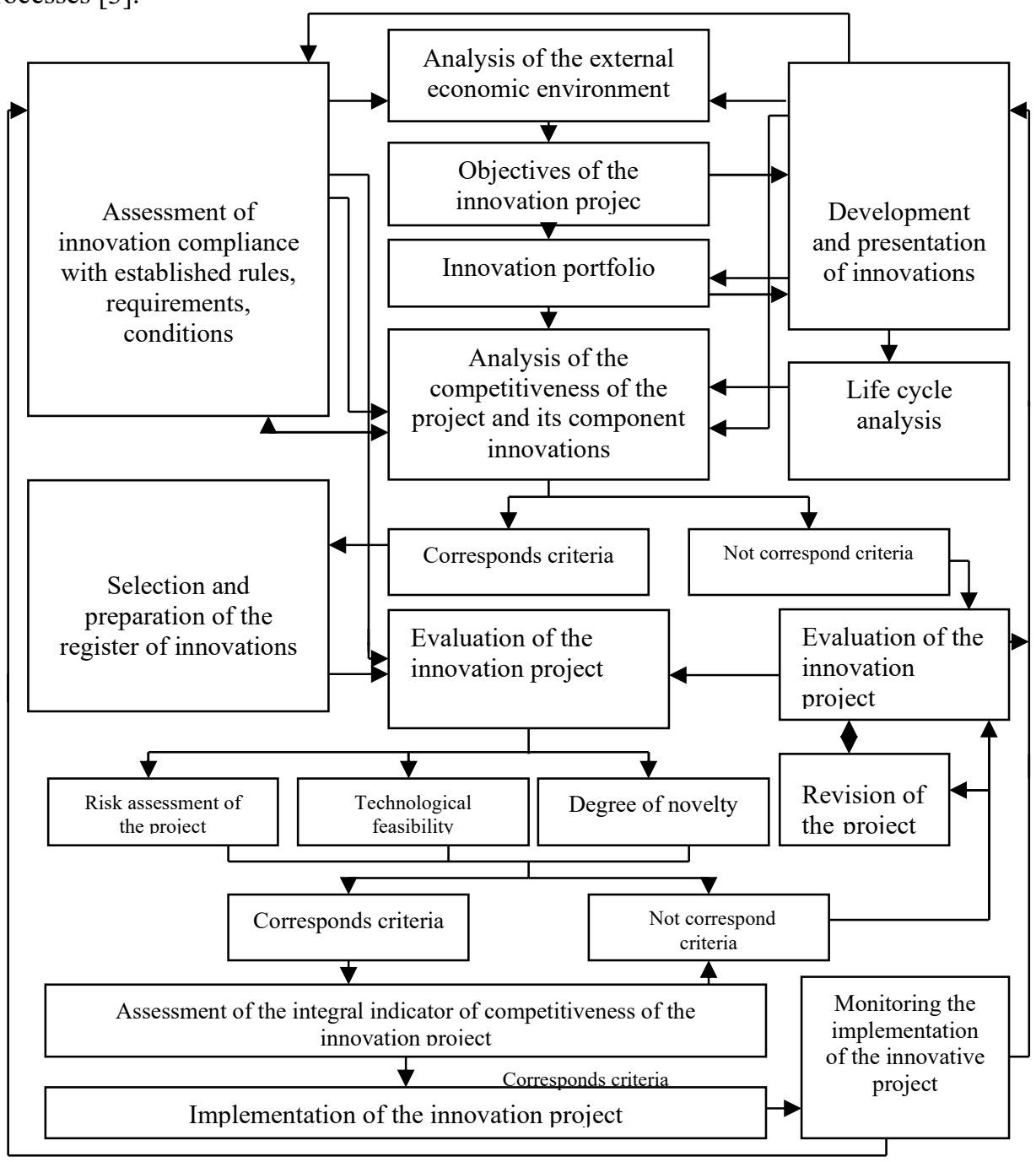

Fig. 2. Model for the development of competitive innovative project. 
An analysis of the factors used to find an integral indicator of the competitiveness of innovation projects makes it possible to identify strengths and weaknesses in the development of innovative activities of a country, region, industry or enterprise and the implemented strategy for innovative development. A general indicator of the competitiveness of innovation projects allows, on the basis of a factor analysis of the indicators included in its composition, proposing measures for the development of the innovative sphere within the framework of economic modernization and innovative development aimed at economic growth and increased cash flow [4].

Multivariate correlation analysis was carried out on the basis of experimental data of 20 innovation projects. At the first stage, factors for correlation analysis were identified, and those that have the most significant effect on the studied competitiveness indicator were selected. At the second, the initial information required for correlation analysis was assessed; at the third stage, the nature and relationship between factors and effective indicators were studied; at the fourth stage, the main indicators of correlation analysis were calculated; at the fifth stage, a statistical assessment of the results of correlation analysis was made and their practical application was discussed.

Based on the studied groups of factors, an equation is proposed for assessing the competitiveness of a project:

$$
K=11.3+0.37 X_{1}+0.21 X_{2}+8.6 X_{3},
$$

where $X_{1} \ldots X_{3}$ - assessed as follows (Table 1).

The integral indicator $K$ makes it possible to predict the competitiveness of an innovation project depending on changes in the presented groups of factors.

The analyzed innovation projects are divided into the following groups:

Group 1 - an integral indicator above 2.25 - these are innovation projects with high competitiveness;

Group 2 - an integral indicator from 1.75 to 2.25 - these are innovation projects with an average level of competitiveness;

Group 3 - an integral indicator below 1.75 - these are innovation projects with a low level of competitiveness.

Table 1. Assessment of competitiveness factors.

\begin{tabular}{|c|c|c|}
\hline $\begin{array}{c}\text { Regression } \\
\text { coefficient }\end{array}$ & $\begin{array}{c}\text { Group of competitiveness } \\
\text { factors }\end{array}$ & Indicators of competitiveness assessment \\
\hline$X_{1}$ & $\begin{array}{c}\text { Competitiveness of innovation } \\
\text { The sum of the following indicators }(0 \text { - "no"; } \\
1-\text { "Yes"): the presence of analogues; the } \\
\text { presence of the market; high quality; } \\
\text { advertising; reputation; affordable price. }\end{array}$ \\
\hline$X_{2}$ & $\begin{array}{c}\text { Efficiency of project results for } \\
\text { investors }\end{array}$ & $\begin{array}{c}\mathrm{Fu}=\mathrm{P} / \mathrm{Pp}, \mathrm{P} \text {-profit before interest and } \\
\text { taxes; P p-interest payable }\end{array}$ \\
\hline$X_{3}$ & $\begin{array}{c}\text { quality of project management } \\
\text { (quality of management } \\
\text { process) }\end{array}$ & $\begin{array}{c}\mathrm{U}=\mathrm{J} * / \mathrm{J}, \mathrm{J} * \text { the number of intellectual } \\
\text { property objects brought to implementation; } \mathrm{J} \\
\text { - the total number of OBI }\end{array}$ \\
\hline
\end{tabular}

An integral indicator allows us to simultaneously analyze the level of competitiveness of an innovation project using a combination of data with obtaining fairly reliable results. The result of the assessment of factors and the calculation of the integral indicator serve as the final indicators focusing on the main problems of ensuring the competitiveness of the innovation project and help to timely correct the identified inconsistencies [5].

An integral indicator of the competitiveness of an innovation project, on the one hand, reflects and characterizes the achieved level of innovative opportunities, and on the other hand, it reveals areas for further development in terms of profit or economic effect, 
achieving economic growth with a high level of competitiveness of the external environment.

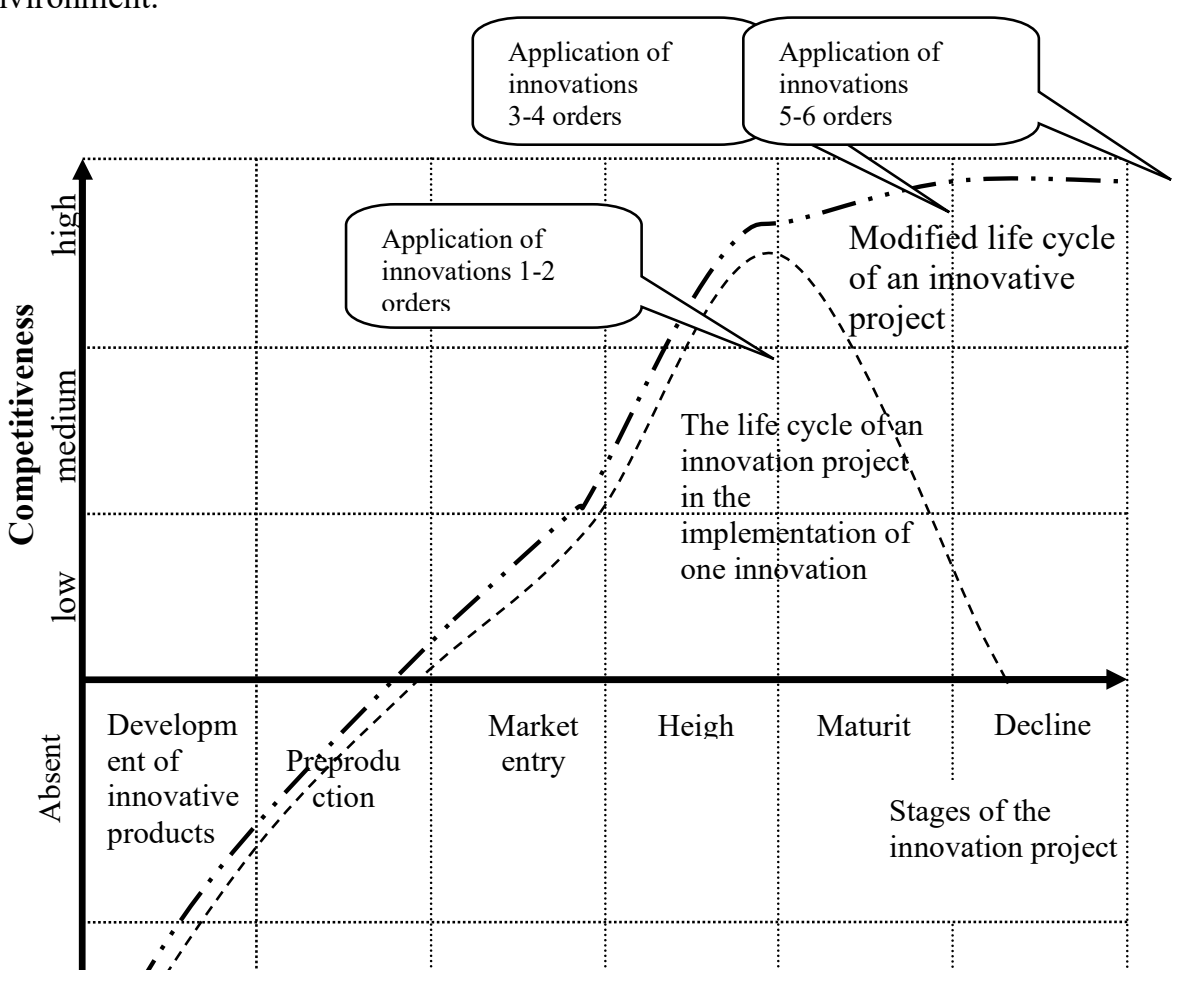

Fig. 3. Relationship between the competitiveness of the innovation project and the life cycle of innovation.

The life cycle of an innovation is a certain period of time during which the innovation is active and brings profit or other real benefits to the manufacturer or seller. The life cycle of an innovation project is a combination of interconnected processes and stages of creating innovation. An innovation project in the general case has the following basic life cycle basis with clearly defined stages: development of innovation, preparation of production, entry into the market, growth, maturity, revival or decline [6]. To maintain the competitiveness of the innovation project at all its stages, it is necessary to develop and implement innovations that are different in their content and level of research intensity, innovations that are in the portfolio of the innovation project and are carried out in a certain sequence (Figure 3, Table 2).

Table 2. Classification of innovations by the depth of changes made by scientific research.

\begin{tabular}{|c|c|c|c|}
\hline $\begin{array}{c}\text { Type of } \\
\text { innovation }\end{array}$ & Order & $\begin{array}{c}\text { Types of innovation by level } \\
\text { of knowledge intensity }\end{array}$ & $\begin{array}{l}\text { Characteristics of the type of } \\
\text { innovation }\end{array}$ \\
\hline \multirow[b]{2}{*}{$\begin{array}{l}\text { Product } \\
\text { innovation }\end{array}$} & First order & Radical innovation & \multirow{2}{*}{$\begin{array}{c}\text { The introduction of new products, } \\
\text { diversification of production, to } \\
\text { maintain an active patent and } \\
\text { licensing policy. }\end{array}$} \\
\hline & $\begin{array}{l}\text { Second- } \\
\text { order }\end{array}$ & Improving innovation & \\
\hline Technologica & $\begin{array}{l}\text { Third } \\
\text { order }\end{array}$ & Reactive innovation & $\begin{array}{l}\text { Equipment upgrade, introduction of } \\
\text { computer-aided design system. }\end{array}$ \\
\hline
\end{tabular}




\begin{tabular}{|c|c|c|c|}
\hline 1 innovation & $\begin{array}{c}\text { Fourth } \\
\text { order }\end{array}$ & Partial innovations & \\
\hline \multirow{2}{*}{$\begin{array}{l}\text { Organization } \\
\text { al and } \\
\text { managerial } \\
\text { innovations }\end{array}$} & Fifth order & Basic innovations & \multirow{2}{*}{$\begin{array}{l}\text { Inventory and cash flow } \\
\text { management. Structuring } \\
\text { relationships between departments. } \\
\text { Strengthening the role of planning } \\
\text { and budgeting, updating personnel. }\end{array}$} \\
\hline & $\begin{array}{l}\text { Sixth } \\
\text { order }\end{array}$ & Strategic innovation & \\
\hline
\end{tabular}

For the successful formation of an innovation project and its further implementation, several options for innovations should be in stock, i.e. "portfolio" of innovative ideas [7]. The paper proposes an algorithm for forming a portfolio of innovations as part of an innovation project (Figure 4).

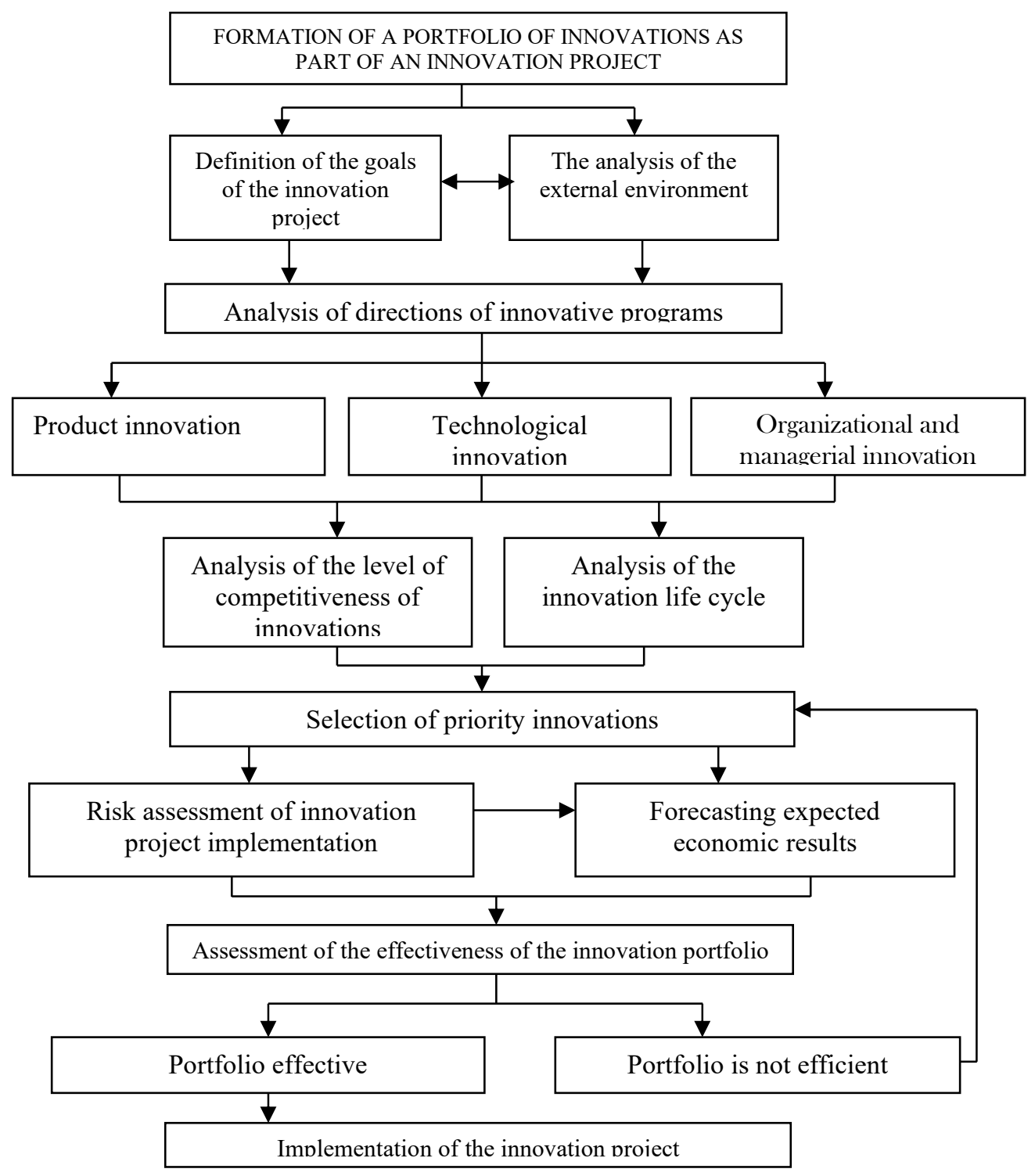

Fig. 4. Algorithm of formation of innovation portfolio as a part of innovation project. 
Assessing the level of competitiveness of each planned innovation in the project portfolio contains the following steps.

1. The choice of the most competitive product (services, technology, management method) as a basis for comparing the competitiveness of innovation.

2. The parameters by which the considered innovation is compared with the existing product are presented in Table 3. To order the criteria, the mathematical and statistical apparatus of expert assessments was used. Expert analysis allowed obtaining weighting factors for determining the competitive position of innovation.

Table 3. Weighting factors of competitiveness of innovation.

\begin{tabular}{|c|c|c|c|}
\hline № & Key factors & Weighting factor & Convention \\
\hline 1. & Purpose of innovation & 0.09 & $\mathrm{~B}_{1}$ \\
\hline 2. & Duration of the innovation life cycle & 0.23 & $\mathrm{~B}_{2}$ \\
\hline 3. & Degree of innovation risk & 0.12 & $\mathrm{~B}_{3}$ \\
\hline 4. & Level of efficiency of innovations & 0.25 & $\mathrm{~B}_{4}$ \\
\hline 5. & Degree of realizability of innovation & 0.14 & $\mathrm{~B}_{5}$ \\
\hline 6. & Degree of novelty of innovation & 0.17 & $\mathrm{~B}_{6}$ \\
\hline 7. & Total & 1.00 & \\
\hline
\end{tabular}

3. Assessment of the competitiveness of innovation by the presented parameters is carried out according to the following formula:

$$
K_{i}=\sum_{i=1}^{6} F_{i n i} * B i / P o i
$$

where $\mathrm{K}_{\mathrm{i}}$ - innovation competitiveness indicator according to the parameters presented in Table $4, \mathrm{i}=1 \ldots 6 ; \mathrm{B}_{\mathrm{i}}$ - the weight of the $\mathrm{i}$-th factor, $\Sigma \mathrm{B}_{\mathrm{i}}=1 ; \mathrm{F}_{\text {ini }}$ - the value of the $\mathrm{i}$-th innovation factor (score in points from 1 to 5); $\mathrm{P}_{\mathrm{oi}}$ - the value of the $\mathrm{i}$-th factor of the competitor sample (score from 1 to 5).

The values of the innovation competitiveness indicator are presented in Table 4.

Table 4. Level of competitiveness innovations in the portfolio.

\begin{tabular}{|c|c|}
\hline Characteristics of innovation competitiveness & $\begin{array}{c}\text { The range of values of the level of } \\
\text { competitiveness of innovation }\end{array}$ \\
\hline High level of competitiveness & $\mathrm{K}_{\mathrm{i}} \in(4 ; 5]$ \\
\hline Average level of competitiveness & $\mathrm{K}_{\mathrm{i}} \in(1.9 ; 4]$ \\
\hline Low level of competitiveness & $\mathrm{K}_{\mathrm{i}} \in(1 ; 1.9]$ \\
\hline Uncompetitive innovation & $\mathrm{K}_{\mathrm{i}} \in[0.2 ; 1]$ \\
\hline
\end{tabular}

A feature of innovation projects is that they are classified as high-risk objects for investment. The author has developed an algorithm for managing the risk of innovation projects (Figure 5).

The localization of risks during the implementation of an innovation project is achieved in the process of analysis and modeling of the portfolio of innovations [8].

The risk management algorithm of innovation projects when changing the duration of their life cycle includes a number of successive stages:

1) identification of factors that increase and decrease the impact of a particular risk on implemented innovations;

2) determination of a system of risk assessment indicators depending on factors influencing an innovation project;

3) identification of potential risk areas;

4) identification of all possible risks of an innovation project. 


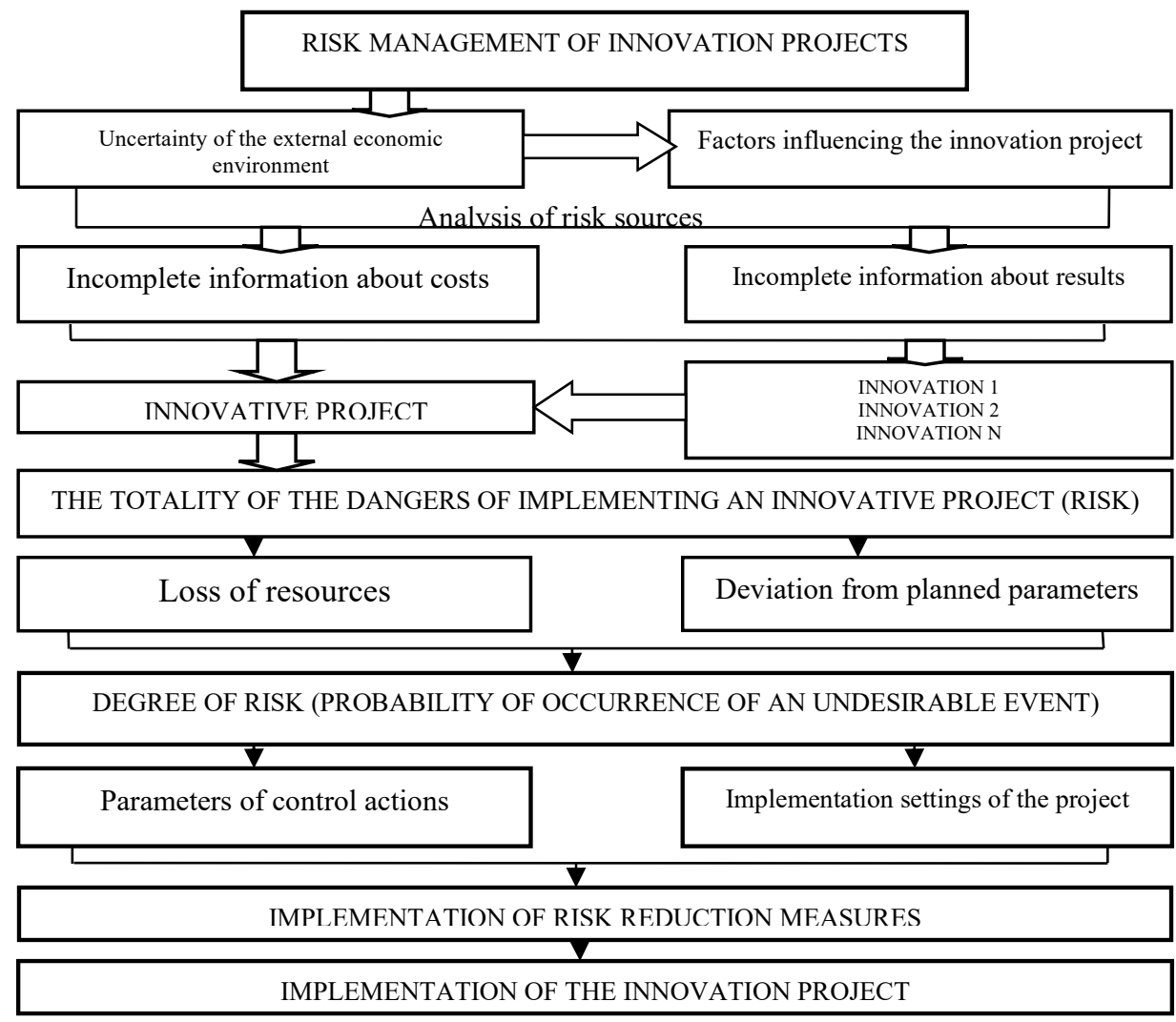

Fig. 5. The algorithm of risk management of innovation projects.

Studying the theory of monitoring studies and analyzing the competitiveness of innovation projects allows formulating common methods for monitoring the competitiveness of an ongoing innovation project [9]. The main stage of the monitoring study is proposed to be an analysis of the competitive position of an innovation project and its innovations. Based on the above formalization, Table 5 presents the possible actions in each specific situation.

Table 5. Areas of implementation of innovation projects.

\begin{tabular}{|c|c|c|c|c|}
\hline \multirow{2}{*}{ Competitiveness } & \multicolumn{4}{|c|}{ Stage in the life cycle of an innovation project } \\
\hline & Market entry & Height & Maturity & Decline \\
\hline High & $\begin{array}{l}\text { Investing faster } \\
\text { than market } \\
\text { demands }\end{array}$ & $\begin{array}{l}\text { Holding the } \\
\text { position of }\end{array}$ & $\begin{array}{l}\text { Holding the } \\
\text { position of }\end{array}$ & $\begin{array}{l}\text { Holding the } \\
\text { position of }\end{array}$ \\
\hline Average & $\begin{array}{l}\text { Increase in } \\
\text { market share }\end{array}$ & $\begin{array}{l}\text { Retention of } \\
\text { shares }\end{array}$ & $\begin{array}{l}\text { Development with } \\
\text { the industry }\end{array}$ & $\begin{array}{c}\text { Summing up or } \\
\text { leaving the } \\
\text { market }\end{array}$ \\
\hline Low & $\begin{array}{c}\text { Selective } \\
\text { approach to } \\
\text { winning positions }\end{array}$ & $\begin{array}{l}\text { Selective increase } \\
\text { in market share }\end{array}$ & $\begin{array}{l}\text { Waiting or } \\
\text { stabilizing }\end{array}$ & $\begin{array}{l}\text { Withdrawal } \\
\text { from the } \\
\text { market }\end{array}$ \\
\hline
\end{tabular}

In the formed matrix, each element (innovation) of the project takes its initial strategic position, which enables management, through their subsequent correction, to choose the 
area of development of an innovation project and significantly reduce the risk of implemented innovations aimed at obtaining the expected economic effect.

Based on the foregoing, the following monitoring methods are proposed that ensure the high competitiveness of an innovation project:

1. Method of full study.

2. Quick assessment method.

3. Method of sequential assessment.

4. Method of modern work.

\section{Conclusion}

The study allows making a conclusion that the theoretical and methodological problems of developing scientific principles for the formation of competitive innovation projects based on the management of their life cycle parameters are of great economic importance, and the solution of these issues is very relevant. The widespread introduction of innovation projects, the continuous creation of new combinations of factors of production have become the norm in modern economic life.

\section{References}

1. I. Karapetyants, Y. Kostuhin, T. Tolstykh, E. Shkarupeta, A. Krasnikova, Proceedings of the 30th International Business Information Management Association Conference (IBIMA) (Madrid, 2017)

2. R. Brazauskas, J. Le-Rademacher, Computer Methods and Programs in Biomedicine, 135, 199-207 (2016)

3. V. Pukhkal, V. Murgul, M. Garifullin, Procedia Engineering, 117, 624-627 (2015)

4. I. Kardes, A. Ozturk, S.T. Cavusgil, E. Cavusgil, International Business Review, 22, 905-917 (2013)

5. E.K. Chirkunova, E.E. Kireeva, A.D. Kornilova, J.S. Pschenichnikova, Procedia Engineering, 153, 112-117 (2016)

6. J. Pelletier, C. Alt, C. Parr, J. Farrell T. Farrell, Proceedings of the Unified International Technical Conference on Refractories UNITECR, 15-20 (2013)

7. S.M.R. Alavipour, D. Arditi, Journal of Construction Engineering and Management, 144(4), 04018012 (2018)

8. S. Zanoni, B. Marchi, M. Pasetti, L. Zavanella, A Supply Chain Model with Integrated Thermal Recovery and Electricity Generation from Industrial Waste Heat. Industrial Efficiency Conference, 11-13 June 2018, Berlin, Germany (2018)

9. F. Aggogeri, A. Borboni, R. Faglia, Applied Mechanics and Materials, 373-375, 130133 (2013) DOI: 10.4028/www.scientific.net/AMM.373-375.130 